\title{
OBJEKTIVITAS PENYALURAN DANA HIBAH (STUDY KASUS PADA PEMERINTAH KABUPATEN BADUNG)
}

\author{
Ni Putu Ayu Kartini Sandiasih, Niluh Ayu Kartika Putri, \\ I Made Tresna Sumarjoyo, Ni Wayan Eni Pramita, Gusti Ayu Oktaviani \\ Jurusan Akuntansi, Universitas Pendidikan Ganesha, Singaraja, Bali Indoneia
}

\begin{abstract}
Abstrak
Penelitian ini bertujuan untuk mengetahui bagaimana gambaran umum organisasi Pemerintah Daerah Kabupaten Badung, apa yang dimaksud dengan dana Hibah, bagaimana prosedur penyaluran dana hibah kepada masyarakat, bagaimana kriteria dan persyaratan penerima dana hibah, Mengapa proposal dana hibah yang diajukan tidak semua diterima serta Faktor-faktor apa saja yang menyebabkan tidak seluruh dana yang diajukan di proposal dapat dicairkan. Proses penyaluran dana hibah tidak semuanya bersifat objektif namun ada yang bersifat subjektif dengan bukti terdapat pengaruh politik dalam penerimaan proposal dana hibah yang diajukan. Pencairan dana hibah yang proposalnya sudah diterima ada yang dicairkan seluruhnya sesuai dengan yang diajukan tetapi ada proposal yang tidak seluruhnya dicairkan sesuai dengan yang diajukan karena beberapa pertimbangan seperti harga barang yang dicantumkan di proposal tidak sesuai dengan kenyataan sehingga Pemerintah Kabupaten Badung akan mencairkan dana sesuai dengan harga barang yang sesungguhnya yang tercantum dalam standar harga biaya Kabupaten Badung.
\end{abstract}

Kata kunci: Dana Hibah,Penyaluran, Objektivitas.

\begin{abstract}
This study aims to find out the general description of the Badung Regency Government organization, what is meant by Grant funds, what is the procedure for channeling grant funds to the community, how are the criteria and requirements for grant recipients, why are the proposed grant funds not all accepted and factors what causes not all of the funds submitted in the proposal can be disbursed. The process of channeling grant funds is not all objective but some are subjective with evidence of political influence in accepting the submitted grant proposal. Disbursement of grant funds whose proposals have been received have been disbursed entirely in accordance with the submitted proposals, but there are proposals that have not been fully disbursed in accordance with the proposals due to several considerations such as the price of goods listed in the proposal not in accordance with reality so that the Government of Badung Regency will disburse the funds in accordance with the prices the actual goods listed in the Badung Regency cost standard.
\end{abstract}

Keywords : Grants, Distribution, Objectivity.

\section{Pendahuluan}

Dalam Undang-Undang Nomor 1 Tahun 2004 tentang Perbendaharaan Negara menetapkan bahwa untuk mendanai dan mendukung kegiatan pembangunan dan dalam rangka mencapai sasaran pembangunan. Pemerintah dapat mengadakan pinjaman dan/atau menerima hibah baik yang berasal dari dalam dan luar negeri. Sebagaimana diamanatkan oleh Undang-Undang Nomor 33 Tahun 2004 tentang Perimbangan Keuangan antara Pemerintah Pusat dan Pemerintahan Daerah, perlu ditetapkan Peraturan Pemerintah yang mengatur tata cara pemberian, penerimaan, dan penggunaan hibah kepada Pemerintah Daerah, baik yang bersumber dari dalam negeri maupun luar negeri.

Menurut kamus besar Bahasa Indonesia (1999) "Hibah" adalah pemberian(sukarela) dengan mengalihkan atas sesuatu kepada orang lain. Dalam Bahasa inggris kata "Hibah" adalah "grant" (dalam jenis kata benda) yang menurut New Webster Dictionary And Thesaurus Of The English Languageadalah act of granting the property. Hibah atau penghibahan dalam pasal 1666 KUHP menyatakan hibah merupakan suatu persetujuan atau perjanjian dengan/dalam pihak yang menghibahkan, pada waktu ia masih hidup, secara cuma-cuma dan tidak dapat ditarik kembali, menyerahkan atau melepaskan sesuatu benda kepada/demi keperluan penerima hibah yang menerima penghibahan itu. 
Setiap Kabupaten di Provinsi Bali menyalurkan dana hibah kepada masyarakat dengan jumlah yang berbeda-beda. Pemerintah daerah di Provinsi Bali yang menyalurkan dana hibah paling banyak adalah Pemerintah Daerah Kabupaten Badung, hal ini dikarenakan pendapatan asli daerah (PAD) Kabupaten Badung tertinggi dibandingkan dengan pemerintah daerah kabupaten lainnya. Pada tahun 2015 pendapatan asli daerah (PAD) Kabupaten Badung sebesar Rp 3 triliun dan pada tahun 2016 pendapatan asli daerah (PAD) Kabupaten Badung dirancang Rp 3,18 triliun. Hal ini menunjukkan peningkatan dari tahun sebelumnya. Semakin besar pendapatan asli daerah (PAD) maka pendapatan daerah juga akan semakin tinggi, sehingga ini akan berdampak kepada anggaran pembelanjaan daerah salah satunya yaitu belanja hibah.

Dana hibah yang disalurkan oleh Pemerintah Kabupaten Badung kepada masyarakat pada tahun 2015 sebesar Rp 144,8 miliar dan pada tahun 2016 direncanakan sebesar Rp 193, 2 miliar dengan jumlah penerima hibah kepada kelompok/anggota masyarakat sebanyak 1.789 penerima. Dari 1.789 penerima hibah tersebut, proposal yang sudah diterima Bagian Administrasi Kesra adalah sebanyak 1.239 proposal dan semua proposal tersebut telah dimohonkan evaluasi kepada SKPD terkait sesuai sifat permohonan.

Jumlah proposal yang diterima tidak sama dengan yang diajukan oleh masyarakat karena ada pertimbangan tertentu yang menyebabkan hanya proposal yang memenuhi syarat yang diterima oleh Pemerintah Kabupaten Badung, selain itu jumlah dana yang dicairkan dari proposal yang sudah diterima tidak sesuai dengan jumlah yang diajukan karena beberapa pertimbangan. Dalasm penerimaan dan penolakan pengajuan dana hibah hal yang dipertimbangkan adalah hal-hal yang bersifat objektif tetapi ada juga yang bersifat subjektif. Factor - factor penerimaan dan penolakan dana hibah seharusnya bersifat objektif agar tidak mementingkan kepetingan pihak tertentu. Objektif yang dimaksudkan adalah dalam proses penyaluran dana hibah penerimaan proposal yang diajukan didasarkan pada aturan yang berlaku umum bukan karena ada factor politik.

Adapun rumusan masalah dari penelitian ini yaitu Bagaimana gambaran umum organisasi Pemerintah Daerah Kabupaten Badung, Apa yang dimaksud dengan dana Hibah, Bagaimana prosedur penyaluran dana hibah kepada masyarakat, Bagaimana kriteria dan persyaratan penerima dana hibah, Mengapa proposal dana hibah yang diajukan tidak semua diterima serta Faktor-faktor apa saja yang menyebabkan tidak seluruh dana yang diajukan di proposal dapat dicairkan.

\section{PEMBAHASAN}

\subsection{Gambaran Umum Organisasi Pemerintah Kabupaten Badung}

Kabupaten Badung, merupakan satu dari delapan kabupaten dan satu kota yang ada di Bali, Terletak pada posisi 08014'17" - 08050'57" Lintang Selatan dan 115005'02" - 115015' 09" Bujur Timur, membentang di tengah-tengah Pulau Bali. Mempunyai wilayah seluas 418,52 km2 ( 7,43\% luas Pulau Bali ).

Secara administratif Kabupaten Badung terbagi menjadi 6 ( enam ) wilayah Kecamatan

yang terbentang dari bagian Utara ke Selatan yaitu Kecamatan Petang, Abiansemal, Mengwi, Kuta, Kuta Utara, \& Kuta Selatan. Disamping itu di wilayah ini juga terdapat 16 Kelurahan, 46 Desa, 369 Banjar Dinas, 164 Lingkungan 8 Banjar Dinas Persiapan dan 8 Lingkungan Persiapan.

Visi Pemerintah Kabupaten Badung

"Memantapkan Arah Pembangunan Badung Berlandaskan Tri Hita Karana Menuju Masyarakat Maju, Damai Dan Sejahtera"

Misi Pemerintah Kabupaten Badung

1. Memperkokoh kerukunan hidup bermasyarakat dalam jalinan keragaman adat, budaya dan agama.

2. Memantapkan kualitas pelayanan publik melalui penerapan teknologi informasi dan komunikasi.

3. Memantapkan tata kelola pemerintah dengan menerapkan prinsip GOOD GOVERNANCE dan CLEAN GOVERNANCE.

4. Meningkatkan kualitas pendidikan, kesehatan dan Keluarga Berencana (KB) dalam pengelolaan kependudukan. 
5. Memperkuat Usaha Mikro Kecil dan Menengah (UMKM) sebagai pilar ekonomi kerakyatan.

Pemerintah Kabupaten Badung sangat memperhatikan wilayahnya sehingga ada beberapa program unggulan yang dilaksanakan dari tahun 2016 hingga tahun 2021, beberapa program tersebut yaitu:

1. Meningkatkan produksi dan produktivitas pertanian dalam arti luas untuk mencapai swasembada pangan melalui pengembangan pertanian kontemporer.

2. Pembangunan infrastruktur wilayah diantaranya Jalan Lingkar Selatan dan Lingkar Barat (Outer Ring Road and Shortcut) di Kecamatan Kuta Selatan serta penataan utilitas umum melalui pembangunan jaringan utilitas terpadu.

3. Meningkatkan distribusi pendapatan kepada masyarakat berpendapatan terendah melalui Program Perlindungan Sosial yang komprehensif di sektor dasar (Pendidikan, Kesehatan, Akses Permodalan).

4. Meningkatkan pelayanan kesehatan masyarakat melalui penyediaan tenaga kesehatan dan sarana prasarana pelayanan kesehatan.

5. Meningkatkan kualitas pendidikan melalui pemenuhan kebutuhan tenaga pendidik dan sarana prasarana pendidikan.

6. Mendorong dan memperkuat lembaga-lembaga pelatihan kerja untuk memperkuat jiwa wirausaha dan penyerapan tenaga kerja.

7. Memperkuat Usaha Mikro Kecil Menengah dan ekonomi kreatif berbasis kerakyatan.

Menyesuaikan dengan kondisi dan potensi wilayahnya, maka Kabupaten Badung dibagi menjadi 3 wilayah Pembangunan yaitu:

a) Wilayah Pembangunan Badung Utara, yang meliputi dua kecamatan yaitu Kecamatan Petang dan Abiansemal dengan pusat pengembangan wilayah di Blahkiuh, dengan dominasi aktivitas perkebunan, tanaman pangan, wisata alam, peternakan, kerajinan rumah tangga dan konservasi alam.

b) Wilayah Pembangunan Badung Tengah, yang meliputi Kecamatan Mengwi dengan pusat pengembangan di Mengwi dengan dominasi aktivitas pertanian, peternakan, pariwisata budaya serta industri kecil dan kerajinan rumah tangga.

c) Wilayah Pembangunan Badung Selatan,yang meliputi Kecamatan Kuta Selatan, Kuta dan Kuta Utara dengan pusat pengembangan di Kuta dan dominasi aktivitas pariwisata, pendidikan, perikanan, industri kecil, serta perdagangan dan jasa.

Struktur Organisasi / Susunan Kelembagaan Pemerintah Kabupaten Badung sesuai dengan Peraturan Pemerintah (PP) Nomor 41 tahun 2007 tentang Organisasi Perangkat Daerah adalah sebagai berikut:

1. Sekretariat Daerah

2. Dinas Daerah

3. Lembaga Teknis Daerah

4. Instansi Vertikal

5. Kecamatan

6. Sekretariat DPRD

7. Perusahaan Daerah

8. Staf Ahli

9. Situs Instansi

Sekretariat DPRD Kabupaten Bandung, dibentuk berdasarkan Peraturan Daerah Nomor 19 Tahun 2007, tentang Pembentukan Organisasi Sekretariat Daerah dan Sekretariat DPRD Kabupaten Bandung. Adapun visi dan misi Sekretariat DPRD Kabupaten Badung sebagai berikut

\section{Visi Sekretariat DPRD Kabupaten Bandung}

"Terwujudnya tata Kelola Sekretariat DPRD yang effektif, effisien, transfaran dan akuntabel dalam menunjang kemitraan antara eksekutif dan legislative".

Misi Sekretariat DPRD Kabupaten Bandung 
a) Meningkatkan upaya pencapaian kinerja secara optimal bagi DPRD dan Sekretariat DPRD, dengan memegang frinsip efektif, efisien, transparan dan akuntabel.

b) Mendorongupaya pemberdayaan dan peningkatan kualitas anggota DPRD.

c) Meningkatkan kualitas dukungan administratif dan fasilitas kegiatan DPRD.

d) Meningkatkan kualitas sumber daya dekretariat DPRD dan aspek intelektual, administrasi dan manajerial

e) Meningkatkan dukungan anggaran yang memadai guna kelancaran pelaksanaan kegiatan alat-alat kelengkapan DPRD.

f) Menyediakan ruang publik sebagai sarana penyampaian informasi dan menampung aspirasi rakyat

g) Meningkatan upaya-upaya mendukung terciptanya hubungan yang harmonis antara eksekutif dan legislatif.

Sekretariat DPRD Kabupaten Bandung mempunyai kedudukan, tugas pokok dan fungsi sesuai dengan Peraturan Kabupaten Badung sebagai berikut:

a. Kedudukan Sekretariat DPRD merupakan unsur pelayanan terhadap DPRD, secara operasional berada dibawah dan bertanggungjawab kepada Pimpinan DPRD dan secara administratif bertanggungjawab kepada Bupati melalui Sekretaris Daerah

b. Sekretariat DPRD dipimpinan oleh seorang Sekretaris.

c. Tugas Pokok, tugas pokok Sekretariat DPRD Kabupaten Bandung adalah memberikan pelayanan administratif kepada Anggota DPRD.

d. Fungsi, Fungsi Untuk menyelenggarakan tugas pokok Sekretariat DPRD Kabupaten Bandung yang mempunyai fungsi:

$>$ Memfasilitasi rapat-rapat anggota DPRD.

$>$ Melaksanakan urusan rumah tangga dan perjalanan dinas para anggota DPRD.

\subsection{Hibah}

$>$ Pengelolaan tata usaha DPRD

Menurut kamus besar Bahasa Indonesia (1999) "Hibah" adalah pemberian (sukarela) dengan mengalihkan atas sesuatu kepada orang lain. Dalam Bahasa inggris kata "Hibah" adalah "grant" (dalam jenis kata benda) yang menurut New Webster Dictionary And Thesaurus Of The English Language adalah act of granting the property. Hibah atau penghibahan dalam pasal 1666 KUHP menyatakan hibah merupakan suatu persetujuan atau perjanjian dengan/dalam pihak yang menghibahkan, pada waktu ia masih hidup, secara cuma-cuma dan tidak dapat ditarik kembali, menyerahkan atau melepaskan sesuatu benda kepada/demi keperluan penerima hibah yang menerima penghibahan itu.

Berdasarkan Peraturan Pemerintah Republik Indonesia Nomor 10 Tahun 2011 tentang Tata Cara Pengadaan Pinjaman Luar Negeri Dan Penerimaan Hibah dan Peraturan Menteri Keuangan Republik Indonesia Nomor 271/PMK.05/2014 tentang Sistem Akuntansi dan Pelaporan Keuangan Hibah, menyatakan bahwa Hibah Pemerintah, yang selanjutnya disebut Hibah, adalah setiap penerimaan negara dalam bentuk devisa, devisa yang dirupiahkan, rupiah, barang, jasa/ atau surat berharga yang diperoleh dari Pemberi Hibah yang tidak perlu dibayar kembali, yang berasal dari dalam negeri atau luar negeri.

Berdasarkan Peraturan Bupati Badung Nomor 47 Tahun 2016 tentang Pedoman Pemberian Hibah, pada Bab 1 yaitu Ketentuan Umum pasal 1 pada poin 14 dijelaskan bahwa Hibah merupakan pemberian uang atau barang atau jasa dari pemerintah daerah kepada pemerintah pusat atau pemerintah daerah lain, Badan Usaha Milik Negara atau Badan Usaha Milik Daerah, Badan, Lembaga dan Organisasi Kemasyarakatan yang berbadan hukum Indonesia, yang secara spesifik telah ditetapkan peruntukannya, bersifat tidak wajib dan mengikat serta tidak secara terus menerus yang bertujuan untuk menunjang penyelenggaraan urusan pemerintah daerah.

Hibah merupakan bentuk bantuan yang tidak harus dikembalikan dan tidak mengikat pihak yang diberi untuk melakukan komitmen tertentu, hibah dapat diberikan dalam bentuk barang, uang maupun jasa. Sedangkan pengelolaan hibah dan bantuan sosial terdiri dari pihak yang melaksanakan fungsi otorisasi adalah Walikota, Wakil Walikota, Sekretaris 
Daerah, Asisten Daerah dan Kepala SKPD dan SKPKD selaku pejabat pengelola keuangan daerah yang melaksanakan fungsi ordonasi.

Pemerintah Daerah dapat memberikan Hibah sesuai kemampuan keuangan Daerah. Pemberian Hibah dilakukan setelah memperioritaskan pemenuhan belanja urusan wajib dan belanja urusan pilihan. Pemberian Hibah ditujukan untuk menunjang pencapaian sasaran program dan kegiatan Pemerintah Daerah sesuai urgensi dan kepentingan Daerah dalam mendukung terselenggaranya fungsi pemerintahan, pembangunan dan kemasyarakatan guna memperhatikan asas keadilan, kepatutan, rasionalitas, dan manfaat untuk masyarakat.

Sesuai dengen pengertian hibah, maka pemberian hibah oleh pemerintah daerah bertujuan untuk menunjang penyelenggaran urusan pemerintah daerah. Pemberian hibah ditujukan untuk menunjang pencapaian sasaran program dan kegiatan pemerintah dengan tetap memperhatikan asas keadilan, kepatutan, rasionalitas, dan manfaat untuk masyarakat serta sesuai dengan asas pengelolaan keuangan daerah. Asas-asas tersebut dapat dijelaskan sebagai berikut:

a. Asas keadilan yaitu terdapat keseimbangan dalam distribusi kewenangan dan penyalurannya dan/atau keseimbangan distribusi hak dan kewajiban berdasarkan pertimbangan objektif

b. Asas kepatutan yaitu tindakan atau suatu sikap yang dilakukan dengan wajar dan proporsional

c. Asas rasionalitas yaitu keputusan atas pemberian hibah harustepat sasaran dan dapat dipertanggungjawabkan

d. Asas manfaat untuk masyarakat yaitu bahwa keuangan daerah harus diutamakan untuk pemenuhan kebutuhan masyarakat dan bermanfaat

e. Asas pengelolaan keuangan daerah berarti bahwa keuangan daerah di kelola secara tertib, taat pada peraturan perundang-undangan, efektif, efisien, ekonomis, transparan, dan bertanggungjawabdengan memperhatikan asas keadilan, kepatutan, dan manfaat untuk masyarakat

Pemberian Hibah memenuhi kriteria paling sedikit :

1. Peruntukannya secara spesifik telah ditetapkan;

2. Bersifat tidak wajib, tidak mengikat atau tidak secara terus menerus setiap tahun anggaran sesuai dengan kemampuan keuangan Daerah kecuali ditentukan lain oleh peraturan perundang-undangan

3. Memberikan nilai manfaat bagi Pemerintah Daerah dalam mendukung terselenggaranya fungsi pemerintahan, pembangunan dan kemasyarakatan

4. Memenuhi persyaratan pemberian Hibah.

Hibah dapat diberikan kepada:

1. Pemerintah Pusat Hibah kepada Pemerintah Pusat diberikan kepada satuan kerja dari kementerian atau lembaga pemerintah non kementerian yang wilayah kerjanya berada di Daerah.

2. Pemerintah Daerah Lain

Hibah kepada pemerintah daerah lainnya diberikan kepada daerah otonom baru hasil pemekaran daerah sebagaimana diamanatkan peraturan perundangundangan.

3. Badan Usaha Milik Negara atau Badan Usaha Milik Daerah

4. Hibah kepada Badan Usaha Milik Negara

5. Hibah kepada Badan Usaha Milik Negara

Hibah kepada Badan Usaha Milik Negara diberikan dalam rangka untuk meningkatkan pelayanan kepada masyarakat sesuai dengan ketentuan peraturan perundang-undangan. Hibah kepada Badan Usaha Milik Daerah diberikan dalam rangka untuk meneruskan hibah yang diterima Pemerintah Daerah dari Pemerintah Pusat sesuai dengan ketentuan peraturan perundangundangan.

6. Badan, Lembaga, dan Organisasi Kemasyarakatan yang berbadan hukum Indonesia. 
Hibah kepada Badan dan Lembaga diberikan kepada Badan dan Lembaga:

a. Bersifat nirlaba, sukarela dan sosial yang dibentuk berdasarkan peraturan perundangundangan;

b. Bersifat nirlaba, sukarela dan sosial yang telah memiliki Surat Keterangan Terdaftar yang diterbitkan oleh Menteri Dalam Negeri, Gubernur atau Bupati; atau

c. Bersifat nirlaba, sukarela bersifat sosial kemasyarakatan berupa kelompok masyarakat/kesatuan-kesatuan masyarakat hukum adat sepanjang masih hidup dan sesuai dengan perkembangan masyarakat, dan keberadaanya diakui oleh pemerintah pusat dan/atau pemerintah daerah melalui pengesahan atau penetapan dari pimpinan instansi vertikal atau kepala satuan kerja perangkat daerah terkait sesuai dengan kewenangannya. Pengesahan atau penetapan yang dimaksud adalah sebagai berikut:

a) Untuk badan atau lembaga atau kelompok masyarakat yang pembentukannya berdasarkan Keputusan, pengesahannya atau penetapannya cukup dengan mengesahkan keputusan dimaksud oleh Instansi Vertikal atau SKPD terkait sesuai dengan tupoksi; dan

b) Untuk badan/lembaga/kelompok masyarakat yang dibentuk tidak berdasarkan Keputusan, maka yang disahkan oleh instansi vertikal atau SKPD terkait adalah struktur organisasi yang bersangkutan diketahui oleh Lurah/Perbekel.

Hibah kepada Organisasi Kemasyarakatan yang berbadan hukum Indonesia diberikan kepada organisasi kemasyarakatan yang berbadan hukum yayasan atau organisasi kemasyarakatan yang berbadan hukum perkumpulan yang telah mendapat pengesahan badan hukum dari kementerian yang membidangi urusan hukum dan hak asasi manusia sesuai peraturan perundang-undangan.

Penyaluran dana hibah harus bersifat objektif agar tidak ada kepentingan tertentu yang diutamakan, adapun pengertian dari objektif sebagai berikut :

a. Objektivitas menurut Lawrence B. Swyer, mortimer A. Dittenhofer dan James H. Scheiner yang diterjemahkan oleh Desi Anhariani (2006:103) adalah "Objektivitas adalah suatu hal yang langka dan hendaknya tidak dikompromikan. Seorang hendaknya tidak pernah menempatkan diri atau ditempatkan dalam posisi di mana objektivitas mereka dapat dipertanyakan. Kode etik dan standar internal telah menetapkan aturan-aturan tertentu yang harus diikuti agar terhindar dari kemungkinan pandangan akan kurangnya objektivitas atau munculnya bias. Pelanggaran atas aturan-aturan ini akan menyebabkan munculnya kritikan dan pertanyaan mengenai kurangnya objektivitas yang dimiliki oleh organisasi."

b. Objektivitas menurut Siti Kurnia Rahayu dann Ely Suhayati (2009:52) adalah "Harus bebas dari masalah benturan kepentingan (conflict of interest) dan tidak boleh membiarkan faktor salah saji material (material misstatement) yang dketahuinya atau mengalihkan pertimbangannya kepada pihak lain. Dengan mempertahankan integritas organisasi akan bertindak jujur,, dan tegas, dengan mempertahankan objektivitasnya, organisasi akan bertindak adil, tidak memihak dalam melaksanakan pekerjaannya tanpa dipengaruhi tekanan atau permintaan pihak tertentu atau kepentingan pribadi".

\subsection{Prosedur Penyaluran Dana Hibah Daerah}

Pemberian Hibah Daerah ditujukan untuk menunjang pencapaian sasaran program dan kegiatan Pemerintah Daerah sesuai urgensi dan kepentingan Daerah dalam mendukung terselenggaranya fungsi pemerintahan, pembangunan dan kemasyarakatan guna memperhatikan asas keadilan, kepatutan, rasionalitas, dan manfaat untuk masyarakat. Prosedur penyaluran dana hibah daerah sesuai dengan Peraturan Bupati Badung Nomor 47 Tahun 2016 tentang Pedoman Pemberian Hibah yaitu :

> Bupati menunjuk SKPD terkait untuk melakukan evaluasi usulan hibah.

$>$ Kepala SKPD terkait menyampaikan hasil evaluasi berupa rekomendasi kepada Bupati melalui TAPD. 
> TAPD memberikan pertimbangan atas rekomendasi sesuai dengan prioritas dan kemampuan keuangan Daerah.

$>$ Rekomendasi kepala SKPD dan Pertimbangan TAPD menjadi dasar pencantuman alokasi anggaran Hibah dalam rancangan KUA dan PPAS.

$>$ Pencantuman alokasi anggaran meliputi anggaran Hibah berupa uang, barang atau jasa. Hibah berupa uang dicantumkan dalam RKA-PPKD. Hibah berupa barang atau jasa dicantumkan dalam RKA-SKPD. RKA-PPKD dan RKA-SKPD menjadi dasar penganggaran Hibah dalam APBD sesuai dengan peraturan perundangundangan.

$>$ Bupati mencantumkan daftar nama penerima, alamat penerima dan besaran Hibah dalam Lampiran III Peraturan Bupati tentang Penjabaran APBD. Pelaksanaan anggaran Hibah berupa uang berdasarkan atas DPA-PPKD. Pelaksanaan anggaran Hibah berupa barang atau jasa berdasarkan atas DPA-SKPD.

$>$ Bupati menetapkan daftar penerima hibah beserta besaran uang dan jenis barang atau jasa yang akan dihibahkan dengan keputusan Bupati berdasarkan peraturan daerah tentang APBD dan peraturan Bupati tentang penjabaran APBD. Daftar penerima hibah menjadi dasar penyaluran/penyerahan hibah. Penyaluran/penyerahan hibah dari pemerintah daerah kepada penerima hibah dilakukan setelah penandatanganan NPHD.

> Bendahara Pengeluaran PPKD meneliti kelengkapan dokumen administrasi belanja Hibah yang diajukan oleh penerima Hibah sebagai dasar menerbitkan Surat Permintaan Pembayaran Langsung (SPP-LS), sebagai bahan penerbitan Surat Perintah Membayar Langsung (SPM-LS) selanjutnya diterbitkan Surat Perintah Pencairan Dana (SP2D) berdasarkan DPA-PPKD sesuai peraturan perundangundangan. Pertanggungjawaban Pemerintah Daerah atas pemberian Hibah meliputi:

a. Usulan dari calon penerima Hibah kepada Bupati

b. Keputusan Bupati tentang Penetapan Daftar Penerima Hibah

c. NPHD

d. Pakta integritas dari penerima Hibah yang menyatakan bahwa Hibah yang diterima akan digunakan sesuai dengan NPHD

e. Bukti transfer uang atas pemberian Hibah berupa uang atau bukti serah terima barang atau jasa atas pemberian Hibah berupa barang atau jasa.

Penerima Hibah juga bertanggung jawab secara formal dan material atas penggunaan Hibah yang diterimanya. Pertanggungjawaban penerima Hibah meliputi :

a. Laporan penggunaan Hibah

b. Surat pernyataan tanggung jawab yang menyatakan bahwa Hibah yang diterima telah digunakan sesuai NPHD

c. Bukti-bukti pengeluaran yang lengkap dan sah sesuai peraturan perundangundangan bagi penerima Hibah berupa uang atau salinan bukti serah terima barang atau jasa bagi penerimaan Hibah berupa barang atau jasa.

Pertanggungjawaban disampaikan kepada Bupati paling lambat tanggal 10 bulan Januari tahun anggaran berikutnya, kecuali ditentukan lain sesuai peraturan perundangundangan. Realisasi Hibah dicantumkan pada laporan keuangan Pemerintah Daerah dalam tahun anggaran berkenaan. Hibah berupa barang yang belum diserahkan kepada penerima Hibah sampai dengan akhir tahun anggaran berkenaan dilaporkan sebagai persediaan dalam neraca.

\subsection{Kriteria dan Persyaratan Penerima Hibah}

Berdasarkan pasal 7 Permendagri Nomor 32 Tahun 2011 menjelaskan bahwa

1) Hibah kepada Badan dan Lembaga diberikan dengan persyaratan paling sedikit sebagai berikut :

a) Memiliki kepengurusan yang jelas di wilayah administrasi Pemerintah Daerah.

b) Kepengurusan sebagaimana dimaksud pada huruf a minimal terdiri dari Ketua, Sekretaris, Bendahara, dan anggota atau sebutan lainnya. 
c) Telah dibentuk paling singkat 2 (dua) tahun.

d) Memiliki surat keterangan domilisi dari Lurah/Perbekel setempat.

e) Berkedudukan dalam wilayah administrasi Pemerintah Daerah.

f) Telah memiliki bukti pengesahan dari SKPD terkait.

2) Hibah kepada Organisasi Kemasyarakatan diberikan dengan persyaratan paling sedikit :

a) Telah terdaftar pada kementerian yang membidangi urusan hukum dan hak asasi manusia paling singkat 3 tahun, kecuali ditentukan lain oleh peraturan perundang-undangan.

b) Berkedudukan dalam wilayah administrasi Pemerintah Daerah.

c) Memiliki sekretariat tetap di wilayah administrasi Pemerintah Daerah.

3) Hibah kepada masyarakat diberikan dengan persyaratan paling sedikit sebagai berikut:

a) Kepengurusan yang jelas

b) Berkedudukan dalam wilayah administrasi pemerintah daerah yang bersangkutan.

Dari penjelasan pasal-pasal yang mengatur tentang siapa-siapa yang boleh menerima hibah dan apa-apa persyaratan penerima hibah sesuai Permendagri Nomor 32 Tahun 2011 dan PP Nomor 2 Tahun 2012, maka dapat dipahami atas beberapa hal sebagai berikut:

1. Penerima hibah sudah diatur secara limitatif yaitu pemerintah; pemerintah daerah lainnya; perusahaan daerah; masyarakat; badan, lembaga, dan organisasi kemasyarakatan; dan badan usaha milik negara atau badan usaha milik daerah;

2. Kedua, hibah kepada masyarakat diberikan dengan persyaratan harus memiliki kepengurusan yang jelas; dan berkedudukan dalam wilayah administrasi pemerintah daerah yang bersangkutan

3. Ketiga, hibah dapat diberikan kepada organisasi kemasyarakatan dengan persyaratan:

$>$ berbadan hukum Indonesia, artinya organisasi kemasyarakatan tersebut berbadan hukum yang didirikan melalui akta notaris dan disahkan oleh Menteri yang terkait

- Telah terdaftar pada pemerintah daerah setempat sekurang-kurangnya 3 (tiga) tahun, artinya organisasi kemasyarakatan tersebut telah terdaftar pada pemerintah daerah sekurang-kurangnya 3 (tiga) tahun melalui satuan kerja perangkat daerah yang mengurusnya, kecuali ditentukan lain oleh peraturan perundang-undangan.

\subsection{Faktor - Faktor Penyebab Proposal Dana Hibah Yang Diajukan Tidak Semua Diterima}

Berdasarkan wawancara yang dilakukan oleh peneliti kepada Pemerintah Kabupaten Badung, didapat hasil sebagai berikut :

\section{Badung.}

Hasil wawancara dengan Staff Pegawai Bagian Keuangan DPRD Kabupaten

I Gede Adi Putrho Sastrawan yang mengatakan bahwa:

Hibah merupakan penyerapan aspirasi dewan dimana secara umum masyarakat akan mengajukan proposal untuk mendapatkan dana hibah ke bagian umum setelah itu baru Bapak Bupati yang melakukan koreksi tetapi di Pemerintah Daerah Kabupaten Badung, anggota dewan yang turun langsung ke lapangan dan menyerap aspirasi dari masyarakat kemudian memilih mana yang memang prioritas untuk mendapatkan dana hibah. Anggota dewan di Pemerintah Daerah Kabupaten Badung mendapatakan proporsi dana yang disalurkan sebagai hibah sebesar Rp 2.000.000.000 untuk masing-masing anggota dewan, jadi anggota dewan tersebut yang mengolah dana yang diberikan untuk desa-desa yang mengajukan hibah. Misalnya di suatu desa membutuhkan dana hibah lebih dari Rp 2.000.000.000 maka akan dibawa langsung ke Bapak Bupati sehingga tidak ada istilah penyerapan yang tidak terpakai.

Hal ini juga tergantung dari sistem politiknya karean sistem politik juga mempengaruhi, jadi kalau sistem politiknya bagus maka penyerapannya juga bagus. Alasan lain yang 
menentukan diterima tidaknya suatu proposal yaitu karena proposal yang diajukan bersifat pribadi. Pribadi disini dimaksudkan yaitu ketika masyarakat mengajukan proposal untuk pembuatan tempat suci tetapi tempat suci yang dimaksudkan bukan tempat suci yang bersifat umum tetapi tempat suci pribadi yang ada di lingkungan rumahnya. Agar dapat diterima proposalnya minimal tempat suci tersebut disusung sebanyak 30 kepala keluarga.

Pada intinya hal yang mempengaruhi penerimaan pengajuan proposal hibah yaitu:

a. Proposal yang diajukan tidak layak

b. Sifat proposal yang diajukan masih bersifat pribadi

c. Adanya permainan politik

\section{Hasil wawancara dengan Ketua Komisi I DPRD Badung} I Wayan Suyasa yang menyatakan bahwa:

Dana hibah yang disalurkan oleh Pemerintah Kabupaten Badung sangat diseleksi dengan ketat sesuai dengan Peraturan Bupati yang disusun berdasar Permendagri No. 14 Tahun 2016 tentang Perubahan Kedua atas Permendagri RI No. 32 tahun 2011 tentang Pedoman Pemberian Hibah dan Bantuan Sosial yang bersumber dari APBD. Hal ini terjadi karena mengingat hibah sangat rawan, maka pemerintah meminta pendampingan dan arahan dari Kajari untuk menghindari adanya permasalahan hukum. Hibah bermasalah sejak tahun 2015, semenjak keluar aturan yang melegalkan hibah hanya bisa diberikan kepada organisasi atau lembaga yang berbadan hukum Indonesia.

Oleh karena hal tersebut maka proposal yang diajukan oleh masyarakat tidak langsung diterima oleh Bupati tetapi melalui SKPD terkait yang ditunjuk oleh Bupati untuk melakukan evaluasi usulan hibah. Kepala SKPD terkait menyampaikan hasil evaluasi berupa rekomendasi kepada Bupati melalui TAPD. TAPD memberikan pertimbangan atas rekomendasi sesuai dengan prioritas dan kemampuan keuangan Daerah. Rekomendasi kepala SKPD dan Pertimbangan TAPD menjadi dasar pencantuman alokasi anggaran Hibah dalam rancangan KUA dan PPAS. Pencantuman alokasi anggaran meliputi anggaran Hibah berupa uang, barang atau jasa.

Selain hal tersebut, proposal yang diterima hanya proposal yang diajukan oleh organisasi atau lembaga yang berbadan hukum di Indonesia. Proyek yang diajukan dalam proposal hanya yang bersifat umum saja yang diterima seperti pura yang disungsung minimal oleh 30 kepala keluarga. Pada dasarnya apabila hibah yang diajukan dapat diterima harus memenuhi syarat, yaitu :

a. Merupakan organisasi atau lembaga berbadan hukum di Indonesia

b. Proyek yang diajukan tidak bersifat pribadi

Hasil wawancara dengan Anggota Komisi IV DPRD Kabupaten Badung I Nyoman Sentana yang menyatakan bahwa:

Hampir semua proposal yang diajukan diterima tetapi ada beberapa yang tidak. Penyebab tidak diterimanya proposal yang diajukan karena proposal yang diajukan tidak layak. Proposal yang tidak layak dimaksudkan adalah proposal yang tidak memenuhi aturan yang ada seperti pengajuan dana hibah untuk kepentingan pribadi. Kepentingan pribadi yang dimaksudkan adalah pengajuan dana hibah untuk perbaikan pura milik pribadi. Dalam hal ini hanya badan atau lembaga yang berbadan hukum saja yang bisa dibantu sedangkan pura tidak. Hibah dapat dicairkan untuk pura dengan syarat pura tersebut terdaftar di daerah masing-masing atau dapat surat hukum dari Dinas Kebudayaan. Pura tersebut harus disungsung minimal 30 kepala keluarga agar bisa mendapatkan dana hibah.

\section{Hasil wawancara dengan Ketua Komisi III DPRD Kabupaten Badung}

\section{Nyoman Satria mengatakan bahwa :}

Hibah yang akan diberikan kepada masyarakat tidak secra langsung diberikan akan tetapi harus dilakukan seleksi terlebih dahulu dan apabila proposal yang diajukan penerima hibah sudah disetujui maka dana tersebut harus digunakan dengan sebaik-baiknya. Bupati Badung menegaskan bahwa "Dana hibah tersebut harus diselesaikan tepat waktu dan dana yang sudah diterima tidak boleh dialihkan kepada orang lain dan apabila penerima hibah tidak dapat menggunakan atau memanfaatkan dana tersebut dengan baik maka diserahkan kembali kepada pemerintah". 
Selama ini, Pemerintah Kabupaten Badung menggelontorkan anggaran yang cukup besar untuk seluruh lembaga adat yang ada di Badung. Baik itu didesa adat ,Banjar adat, dan yang lain. Namun karena masalah regulasi pemerintah daerah, khawatir jika pemberian dana hibah melanggar akan terjadi suatu temuan. Dan yang kena imbas selain pemberi juga penerima. Mengingat lembaga adat seperti desa adat ,tempat ibadah (pura), banjar adat, subak dan seka truna-truni, merupakan sebuah kesatuan masyarakat hukum adat yang telah ada dan diakui secara turun-temurun oleh masyarakat. Lembaga tersebut juga membantu pemerintahan dalam pembangunan dan kemasyarakatan. Oleh karena itu, Pemerintah Kabupaten Badung minta agar lembaga itu tetap diberikan kucuran hibah.

\section{Hasil wawancara dengan Anggota Komisi I DPRD Kabupaten Badung \\ Kadek Sudarmaja mengatakan bahwa:}

Hibah hanya diberikan pada saat kegiatan yang bersifat umum /tdk pribadi karena Hibah bersifat bantuan untuk menunjang program pembangunan sesuai dengan prioritas dan kebijakan Pemerintah serta merupakan urusan daerah. Menurut pasal 5 hibah yang bersumber dari pendapatan dalam negeri, diberikan kepada Daerah adanya kriteria, yaitu untuk melaksanakan kegiatan yang menjadi urusan daerah yaitu peningkatan fungsi pemerintah dan pemberdayaan aparatur Daerah. Untuk kegiatan dengan kondisi tertentu yang berkaitan dengan penyelenggaraan kegiatan pemerintah yang berskala nasional dan atau untuk melaksanakan kegiatan sebagai akibat kebijakan pemerintah yang mengakibatkan penambahan beban APBN. Pengusulan dan penilaian pemberian hibah dilihat dari tata cara perencanaan dan pengajuan usulan kegiatan sebagaimana yang dimaksud dalam pasal 10 yang dilakukan sesuai peraturan Menteri Negara Perencanaan Pembangunan Nasional.

\subsection{Faktor-Faktor Yang Menyebabkan Tidak Seluruh Dana Yang Diajukan Di Proposal Dapat Dicairkan}

Berdasarkan wawancara yang dilakukan oleh peneliti kepada Pemerintah Kabupaten Badung, didapat hasil sebagai berikut :

\section{Badung}

Hasil wawancara dengan Staff Pegawai Bagian Keuangan DPRD Kabupaten

I Gede Adi Putrho Sastrawan yang menyatakan bahwa:

Dana hibah yang diajukan bisa semuanya dicairkan sesuai dengan yang diajukan dalam proposal dana hibah atau tidak. Dana hibah yang dicairkan tidak sesuai dengan yang diajukan dalam proposal karena harga yang tercantum di proposal di mark up oleh pengusul sehingga jumlah yang dicairkan akan disesuaikan dengan daftar harga barang yang dimiliki oleh Pemerintah Kabupaten Badung. Pemerintah Kabupaten Badung mempunyai standar harga biaya Kabupaten Badung yang dijadikan sebagai acuan dalam membandingkan harga yang diproposal dengan harga yang ada dipasaran karena banyak pengusul proposal yang melakukan mark up harga untuk keuntungan pribadinya.

\section{Hasil wawancara dengan Ketua Komisi I DPRD Badung}

I Wayan Suyasa yang menyatakan bahwa:

Dana hibah yang diajukan akan sepenuhnya dicairkan sesuai dengan yang diajukan namun ada dana hibah yang dicarikan tidak sesuai dengan yang diajukan karena pertimbangan seperti penilaian harga barang yang dibandingkan dengan standar harga biaya Kabupaten Badung.

\section{Hasil wawancara dengan Anggota Komisi IV DPRD Kabupaten Badung}

I Nyoman Sentana yang menyatakan bahwa:

Pencairan dana hibah disesuaikan dengan standar harga biaya Kabupaten Badung apabila sesuai dengan harga yang tertera di standar harga biaya Kabupaten Badung maka dana yang dicairrkan sesuai dengan yang diajukan tetapi jika tidak sesuai maka dana yang dicairkan akan disesuaikan dengan perkiraan harga barang yang tertera di standar harga biaya Kabupaten Badung untuk mencegah penyalahgunaan dana yang diberikan.

Hasil wawancara dengan Ketua Komisi III DPRD Kabupaten Badung

I Nyoman Satria mengatakan bahwa :

Hibah merupakan penyerapan aspirasi dewan dimana secara umum masyarakat akan mengajukan proposal untuk mendapatan dana hibah kebagian umum. Hinah yang 
dapat dicairkan oleh pemerintah yaitu hibah yang biayanya setara antara perhitungan pemberi dan penerima hibah. Jika biaya yang diajukan oleh penerima hibah melebihi maka bagian pemberi akan mengecek ulang harga barang yang diajukan oleh penerima, apabila perhitungan benar maka hibah dapat dicairkan dan apabila perhitungannya melebihi maka hibah akan dicairkan akan tetapi jumlah yang cair atau keluas tidak sesuai dengan yang diajukan oleh pemerima. Hal tersebut dilakukan untuk menjaga agar penerima tidak bertindak seenknya atau sewenang- wenang dalam menentukan jumlah dana yang akan dicantumkan.

\section{Hasil wawancara dengan Anggota Komisi I DPRD Kabupaten Badung Kadek Sudarmaja mengatakan bahwa:}

Dana yang dicairkan full maupun tidak itu tergantung dari penerima dana hibah, jika dana hibah tidak sesuai dengan kenyataan maka tugas dari pemberi dana hibah yaitu untuk mengecek ulang laporan tersebut jika selisih biaya besar maka pemberi hibah akan mengeluarkan ataupun mencairkan dana tersebut akan tetapi dana tersebut tidak akan keluar atau cair sebesar yang dicantumkan oleh penerima dana hibah di proposal tersebut. Bupati Badung menekankan dana hibah ini merupakan kewajiban pemerintah, namun dalam upaya program percepatan pembangunan di daerah Badung demi kesejahteraan bersama. Hibah kepada masyarakat diberikan kepada masyarakat dengan persyaratan paling sedikit, memiliki kepengurusan yang jelas dan berkependudukan dalam wilayah administrasi pemerintah daerah yang bersangkutan. Hinah kepada organisasi kemasyarakatan diberikan persyaratan paling sedikit yaitu telah terdaftar pada pemerintah daerah setempat sekurangkurangnya 3 tahun, kecuali ditentukan lain oleh peraturan perundang-undangan dan berkependudukan dalam wilayah administrasi pemerintah daerah yang bersangkutan, memiliki secretariat yang tetap.

Adapun Pelaporan dan pertanggungjawaban penerima dana hibah :

1. Penerima hibah berupa uang harus menyampaikan laporan penggunaan hibah kepada Kepala Daerah melaui PPKD dengan tembusan SKPD terkait.

2. Penerima hibah berupa barang atau jasa menyampaikan laporan penggunaan hibah kepada Kepala Daerah melalui Kepala SKPD terkait.

\section{PENUTUP}

\subsection{Simpulan dan saran}

Berdasarkan pemaparan di atas dapat disimpulkan bahwa Hibah atau penghibahan dalam pasal 1666 KUHP menyatakan hibah merupakan suatu persetujuan atau perjanjian dengan/dalam pihak yang menghibahkan, pada waktu ia masih hidup, secara cuma-cuma dan tidak dapat ditarik kembali, menyerahkan atau melepaskan sesuatu benda kepada/demi keperluan penerima hibah yang menerima penghibahan itu. Prosedur penyaluran dan kriteria penerima dana hibah sudah diatur dalam Peraturan Bupati Badung Nomor 47 Tahun 2016 tentang Pedoman Pemberian Hibah. Proposal pengajuan dana hibah sangat banyak namun tidak semua proposal bisa disetujui untuk didanai, karena faktor-faktor tertentu.

Factor - factor yang mempengaruhi penerimaan dana hibah yaitu proposal yang diajukan harus layak. Layak yang dimaksudkan adalah proyek yang diajukan dalam proposal tersebut tidak bersifat pribadi atau hanya untuk kepentingan pribadi sebagai contoh membangun sanggah yang dimilik pribadi. Pura dapat didanai apabila pura tersebut sudah terdaftar di masing-masing banjar atau mendapat surat hukum dari dinas kebudayaan dan disusung oleh minimal 30 kepala keluarga. Hanya badan atau lembaga yang berbadan hukum saja yang didanai oleh Pemerintah Kabupaten Badung. Selain hal tersebut hal yang dipertimbangkan dalam penerimaan proposal dana hibah adalah pengaruh politik, jadi jika sistem politiknya bagus maka penyerapannya juga bagus.

Hal ini menunjukan bahwa dalam proses penyaluran dana hibah tidak semuanya bersifat objektif namun ada yang bersifat subjektif dengan bukti terdapat pengaruh politik dalam penerimaan proposal dana hibah yang diajukan. Pencairan dana hibah yang proposalnya sudah diterima ada yang dicairkan seluruhnya sesuai dengan yang diajukan tetapi ada proposal yang tidak seluruhnya dicairkan sesuai dengan yang diajukan karena beberapa pertimbangan seperti harga barang yang dicantumkan di proposal tidak sesuai dengan kenyataan sehingga Pemerintah Kabupaten Badung akan mencairkan dana sesuai 
dengan harga barang yang sesungguhnya yang tercantum dalam standar harga biaya Kabupaten Badung. Standar harga biaya Kabupaten Badung merupakan suatu dokumen yang berisi daftar harga setiap barang di Kabupaten Badung. Adapun saran yang didapat dari simpulan yaitu Dana hibah merupakan dana yang disalurkan kepada masyarakat yang bertujuan untuk meningkatkan pembangunan desa. Dana hibah sangat penting untuk kemajuan desa sehingga perlu disalurkan secara objektif. Penyaluran dana hibah secara objektif adalah penyaluran dana hibah dengan memperhatikan ketentuan yang berlaku tidak memandang siapa yang dibantu karena apabila dipengaruhi oleh factor subjektif maka kesempatan masyarakat yang membutuhkan dana tidak bisa terpenuhi karena pihak penyalur lebih mementingkan politiknya, sehingga sudah seharusnya dana hibah disalurkan tanpa melihat subjektif tetapi objektif.

https://id.wikipedia.org/wiki/Hibah

DAFTAR PUSTAKA

http://kbbi.web.id/objektivitas

http://idih.badungkab.go.id/uploads/PERBUP 47 2016.pdf

http://bawaslu.go.id/sites/default/files/lain-

lain/PMK\%20191\%20Tahun\%202011\%20Mekanisme\%20Pengelolaan\%20Hibah.pdf

http://samarinda.bpk.go.id/wp-

content/uploads/2015/02/Tulisan Hukum 2014 Hibah APBD.pdf 